\title{
ИССЛЕДОВАНИЕ ПАМЯТНИКОВ АРХЕОЛОГИИ В УРОЧИЩЕ КЫЗЫЛКОЛЬ
}

\author{
(C) 2021 г. Подушкин Александр Николаевич1, \\ Донец Андрей Геннадиевич ${ }^{2}$ \\ ${ }^{1}$ автор-корреспондент, доктор исторических наук, профессор, \\ Южно-Казахстанский государственный педагогический университет, \\ г. Шымкент, Казахстан. E-mail: p a n alex@mail.ru \\ ${ }^{2}$ старший научный сотрудник, Туркестанский областной историко-краеведческий \\ музей, г. Шымкент, Казахстан. E-mail: foto-ad@mail.ru
}

\begin{abstract}
Аннотация. Статья посвящена первым результатам картографического и рекогносцировочного обследования нового историко-культурного региона вблизи озера Кызылколь: проведены разведочные работы на семи могильниках, одиночных крупных курганах, городище Актобе кызылкольское и каменном сооружении на сопке Кызылсенгир - на последних двух объектах произведён сбор подъёмного материала и заложены рекогносцировочные шурфы. Концентрация здесь на сравнительно ограниченной территории одновременно нескольких масштабных археологических объектов позволяет рассматривать этот оазис на северных склонах Каратау как самостоятельную историко-культурную зону большой научной и социальной значимости, названную «кызылкольской». Первоначальные работы на археологических объектах данной местности позволили определить принадлежность и хронологию памятников, связанных с древним народонаселением, жившим здесь в первой половине I тыс. н.э. (время существования государства Кангюй).
\end{abstract}

Ключевые слова: археология, Кангюй, картография, разведочный шурф, памятники

\section{ҚЫЗЫЛКӨЛ ШАТКАЛЫНДАҒЫ АРХЕОЛОГИЯЛЫК ЕСКЕРТКІШТЕРДІ ЗЕРТТЕУ}

\section{Александр Николаевич Подушкин ${ }^{1}$, Андрей Геннадиевич Донец ${ }^{2}$}

${ }^{1}$ корреспондент авторы, тарих ғылымдарының докторы, профессор, Оңтүстік Қазақстан мемлекеттік педагогикалық университеті, Шымкент қ., Қазақстан. E-mail: p_a_n_alex@mail.ru 2аға ғылыми қызметкер, Түркістан облыстық тарихи-өлкетану музейі, Шымкент қ., Қазақстан. E-mail: foto-ad@mail.ru

Аннотация. Мақала Қызылкөлге жақын жаңа тарихи-мәдени аймақты картографиялық-алдын-ала барлау зерттеу жұмыстарының алғашқы нәтижелеріне арналған: жеті обаға, жеке дара тұрған ірі қорғандаға, қызылкөлдік Ақтөбе қалашығына және Қызылсеңгір шоқысындағы тас құрылысқа барлау жұмыстары жүргізілді соңғы екі нысанда көтергіш материалды жинау мен барлау бұрмашегесі орнатылды. Мұндағы салыстырмалы түрде шектеулі аумақта бірнеше ауқымды археологиялық нысандардың шоғырлануы осы оазисті Қаратаудың солтүстік беткейлерінде тәуелсіз тарихи және «Қызылкөл» деп аталатын ғылыми және әлеуметтік маңызы зор мәдени аймақ деп қарастыруға мүмкіндік береді. Осы жердегі археологиялық орындарындағы 
алғашқы жұмыстар бұл ескерткіштердің біздің заманымыздың I мыңж. бірінші жартысында осы жерде өмір сүрген ежелгі халыққа тиесілігі мен хронологиясын (Кангюй мемлекетінің өмір сүрген уақыты) анықтауға мүмкіндік берді.

ескерткіштер

Түйін сөздер: археология, Кангюй, картография, барлау шұңқыры,

\title{
RESEARCH OF ARCHEOLOGICAL MONUMENTS IN THE KYZYLKOL TRACT
}

\author{
Podushkin Alexander ${ }^{1}$, Donets Andrey ${ }^{2}$ \\ ${ }^{1}$ corresponding author, Doctor of Historical Sciences, Professor, \\ South Kazakhstan State Pedagogical University, \\ Shymkent, Kazakhstan. E-mail:p_a_n_alex@mail.ru \\ ${ }^{2}$ Senior Researcher, Turkestan Regional Museum of History and Local Lore, \\ Shymkent, Kazakhstan. E-mail: foto-ad@mail.ru
}

\begin{abstract}
The article is devoted to the first results of a cartographic and reconnaissance survey of a new historical and cultural region near Lake Kyzylkol: exploration work was carried out on seven burial grounds, on single large mounds, on the settlement of Kyzylkol Aktobe and on a stone structure on the Kyzylsengir hill - on the last two objects lifting material was collected and reconnaissance pits were laid. The concentration here on a relatively limited territory of several large-scale archaeological objects allows us to consider this oasis on the northern slopes of Karatau as an independent historical and cultural zone of great scientific and social significance, called "Kyzylkol". Initial work on the archaeological sites of this area made it possible to determine the belonging and chronology of the monuments associated with the ancient population that lived here in the first half of the 1st millennium $\mathrm{AD}$ (the time of the existence of the Kangju state).
\end{abstract}

Keywords: archaeology, Kangju, cartography, exploration pit, sites

\section{Введение}

В течение полевых сезонов 2019-2020 гг. археологический отряд Южно-Казахстанского государственного университета совместно с сотрудниками Туркестанского областного историко-краеведческого музея и Центрального государственного музея Республики Казахстан осуществляли картографические, рекогносцировочные работы на группе памятников археологии кызылкольской историкокультурной зоны (далее - КИКЗ, прим. авт.) (Туркестанская обл., Сузакский p-н, в 8,3 км к Ю3 от п. Кумкент). Обследовано семь могильников, одиночные крупные курганы, городище Актобе кызылкольское и каменное сооружение на сопке Кызылсенгир (на последних двух объектах произведён сбор подъёмного материала и зало-

жены рекогносцировочные шурфы). Ниже представленная информация освещает первоначальные результаты указанных работ.

Ландшафтная, г гидрологическая характеристика региона

В ландшафтно-географическом плане оз. Кызылколь находится в предгорьях северных склонов Каратау, у подножия двух горных массивов - Улькенактау и Тау-Тары, в 156 км на север от г. Шымкент (Туркестанская обл., Сузакский р-н), на высоте от 330 до 320 м над уровнем моря, а некоторые сопки, окружающие озеро, возвышаются до 420 м. Озеро древнее, на это указывают неогеновые глины красного цвета по берегам Кызылколя, возраст которых приближается к 23 млн лет. Это обстоятельство опре- 
делило и название озера (в переводе с каз. яз. «Красное озеро»- прим. авт.).

С востока берег озера окаймлён вытянутой длинной возвышенностью с плоской вершиной, которая завершается к югу конусовидным бугром под названием Кызылсенгир (в переводе с каз. яз. «Красная сопка»; иное название - Шошактобе - прим. авт.), здесь же в оз. Кызылколь впадает единственная река грунтово-родникового происхождения Ушбас (рис. 1). С запада озеро обрамляют округлые крас- ные склоны из неогеновых глин, южный берег подпирают скальные выходы гор Тау-Тары, здесь фиксируются лёссовые участки с родниками. C севера к озеру из урочища Акжар ведёт сухое русло Тасабайсая, которое раз в несколько лет наполняется водами весеннего Таласа.

История изучения объектов археологии на территории КИКЗ

Изысканий, включающих научное изучение археологических объ-

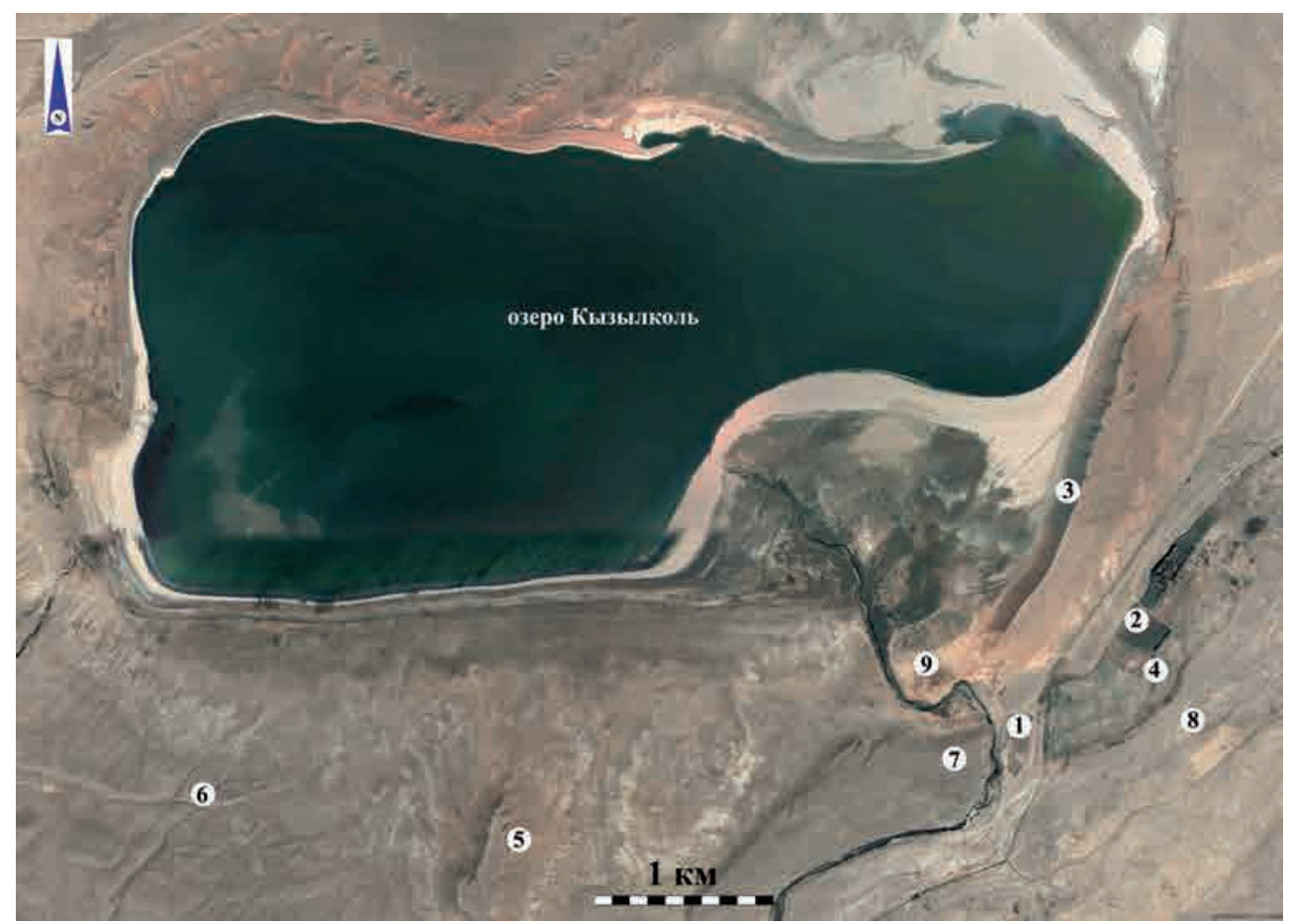

Рис. 1. Картография памятников археологии II-V вв. н.э. кызылккольской историко-культурной зоны: 1 -могильник Кызылколь 1 (западная группа насыпей); 2 - могильник Кызылколь 1 (восточная группа насыпей); 3 -могильник Кызылколь 2; 4 -могильник Кьззылколь 3; 5 -могильник Кызыллколь 4; 6-могильник Кызылколь 5;

7 - одиночные курганы на южном останцее (левый берег р. Уибас);

8 - поселение Актобе кызылкольское; 9 - храм-святилище Кызылсенгир

Fig. 1. Cartography of archaeological monuments of the II-V centuries AD of the Kyzylkol historical and cultural zone: 1 - Kyzylkol 1 burial ground (western group of embankments); 2 -Kyzylkol 1 burial ground (eastern group of embankments); 3 - Kyzylkol 2 burial ground; 4 -Kyzylkol 3 burial ground; 5 - the burial ground Kyzylkol 4; 6-the burial ground Kyzylkol 5; 7 - single mounds on the southern remnant (left bank of the river Ushbas); 8 - the settlement of Kyzylkol Aktobe; 9 - temple-sanctuary Kyzylsengir 
ектов на территории КИКЗ, ранее не проводилось. Первая информация об археологических объектах у оз. Кызылколь в 1950-1960 гг. ограничена только фактом их выявления и картографической фиксации с минимальным описанием. Так, один могильник был отмечен Е.И. Агеевой в ходе рекогносцировочных исследований северных склонов Каратау отрядом ЮКАЭ [Агеева, 1954, с. 83-86].

В «Археологической карте Казахстана» приведены данные об одном могильнике и поселении: лист 36, квадраты К-12, 13; Л-12, 13; № 3432 и 3433 [АКК, 1960, с. 239]. В таком же ключе упомянуты два памятника в районе оз. Кызылколь (поселение и могильник), обозначенные только на карте [Сенигова, Мерщиев, Максимова, 1962, с. 6].

Более обстоятельные данные о памятниках археологии вблизи оз. Кызылколь (топографические планы, фотографии, обмеры, анализ подъёмного материала трёх могильников и поселения) были получены в ходе поисковой разведки археологического отряда Чимкентского педагогического института (руководители Н.П. Подушкин*, А.Н. Подушкин) в рамках паспортизации археологических объектов Сузакского района Южно-Казахстанской области и включения их в Свод памятников [Свод..., 1994, с. 245-246; № 531-533, 535].

Эпизодически, начиная с 2004 по 2018 г., в районе оз. Кызылколь, силами археологического отряда ЮжноКазахстанского государственного педагогического университета и отдела археологии Туркестанского областного историко-краеведческого музея осуществлялись рекогносцировочные работы, позволившие выявить памятники эпохи камня и сделать сборы каменных артефактов X-V тыс. до н.э.

Археологическая картография, фиксаичя и количественная составляюшая памятников

В непосредственной близости от оз. Кызылколь и р. Ушбас расположены несколько крупных могильников (курганных полей), включающих более 300 курганов, городище Актобе кызылкольское, каменное сооружение на холме Кызылсенгир, вместе представляющих компактный оазис.

В частности, в пределах КИКЗ зафиксированы следующие археологические объекты.

Могильник Кызылколь 1 (западная группа насыпей, 66 курганов). Объект находится на невысокой плоской площадке неправильной трапециевидной формы размерами $150 \times 240 \times 120 \times 180$ м правой надпойменной террасы безымянного ручья, вблизи его впадения в р. Ушбас, у подножия южного окончания языкового выступа из неогеновых глин. Относится к могильникам с бессистемным расположением насыпей, которые сложены из небольших камней, мелкого щебня и грунта. Профили насыпей фиксируются хорошо, но есть курганы с сильно оплывшими склонами. Средние размеры насыпей: диаметр основания 18-12, 12-20 м, высота 0,6-1,9 м (часть курганов носит следы ограбления в древности) (рис. 1,$1 ; 2$ ).

Могильник Кызылколь 1 (восточная группа насыпей; 30 курганов) расположен на кромке правой невысокой надпойменной террасы безымянного

*Об Н.П. Подушкине подробнее см.: [Подушкин А.Н., 2019]. Прим. авт. 


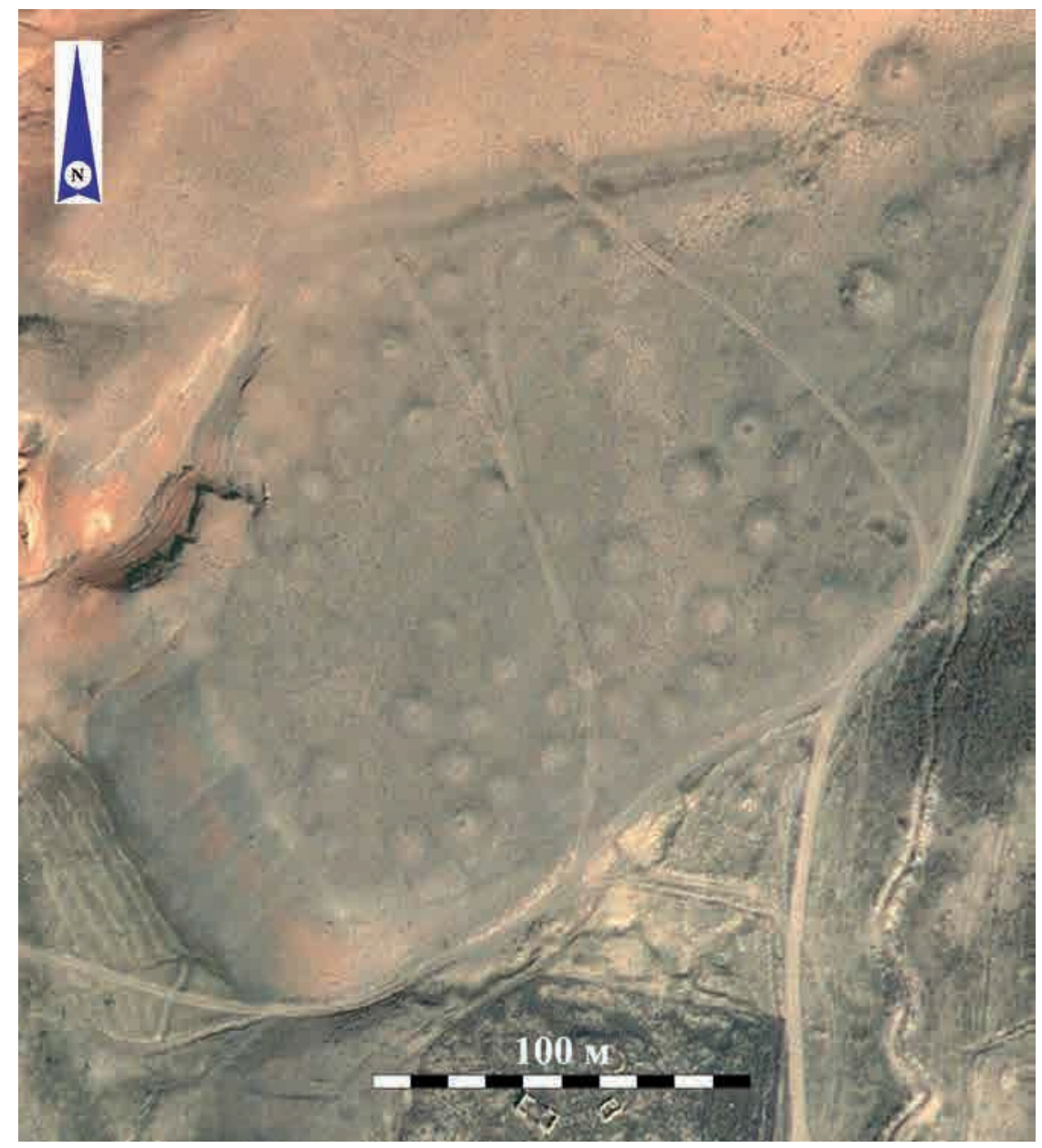

Рис. 2. Могильник Кызылколь 1 (западная группа насыпей). Вид сверху

Fig. 2. Burial ground Kyzylkol 1 (western group of embankments). Top View

ручья, вытянутой с северо-востока на юго-запад, при этом отмечено расположение насыпей цепочкой. В остальном все характеристики этого могильника (состав насыпей, параметры курганов) аналогичны вышеописанному могильнику Кызылколь 1 западной группы курганов (рис. 1, 2).

Могильник Кызылколь 2 (более 60 курганов) зафиксирован на плоской площадке вытянутого языковидного останца из неогеновых глин длиной более 2,2 км, находящегося у юговосточной береговой линии оз. Кызылколь. Объект характеризуется расположением насыпей в 1-2 цепочки, а также группами курганов, расположенных бессистемно; при этом у юго-восточного основания останца также отмечена отдельная цепочка насыпей. Все округлые в плане насыпи сложены из среднего размера камней и щебня вперемежку с грунтом. Размеры курганов различны: отмечены несколько крупных насыпей (диаметр основания 16-22 м, высота 1,6-1,8 м), однако основная масса курганов имеет средние и небольшие размеры (диаметр основания 6-8, 10-12 м, высота 0,6-1,2 м). Многие насыпи носят сле- 
Подушкин А.Н., Донец А.Г. Исследование памятников археологии в урочище Кызылколь

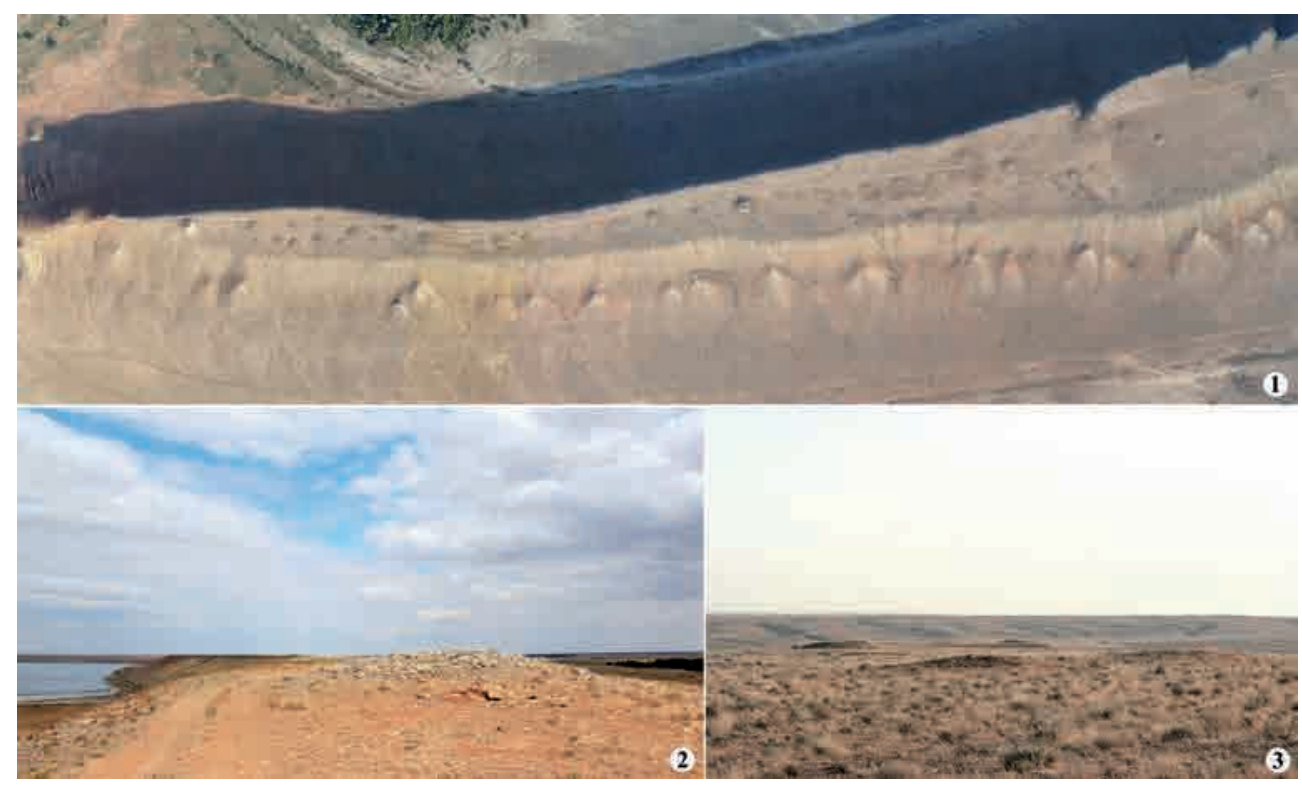

Рис. 3. Могильник Кызылколь 2: 1-вид сверху; 2-вид одного из курганов; 3 -насыпи

Fig. 3. Burial ground Kyzylkol 2: 1-top view; 2-view of one of the mounds; 3 - embankments

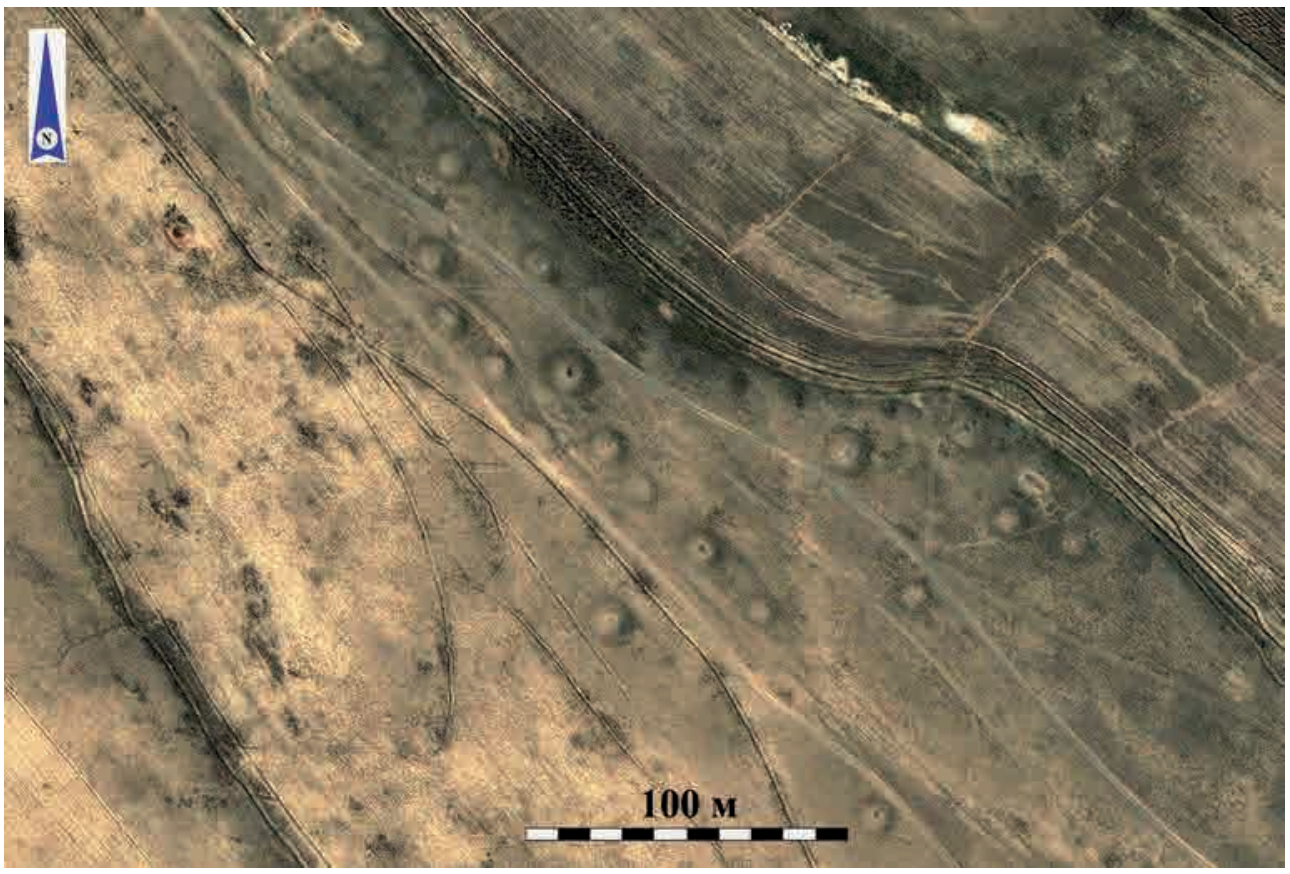

Рис. 4. Могильник Кыззилколь 3. Вид сверху

Fig. 4. Burial ground Kyzylkol 3. Top View 
ды древних грабительских раскопок (рис. 1, 3; 3, 1-3).

Могильник Кызылколь 3 (25 курганов). Объект расположен на кромке левой невысокой надпойменной террасы безымянного ручья, которая вытянута с северо-запада на юго-восток, в 370 м к югу от могильника Кызылколь 1 восточной группы насыпей. Курганы сложены из мелкого камня, щебня и грунта, расположены цепочкой (отмечены две цепочки). Средние параметры насыпей: диаметр основания 10-12, 13-20 м, высота 0,7-1,6 м (часть насыпей носит следы раскопок древних грабителей) (рис. 1, 4; 4).

Могильник Кызылколь 4 (6 курганов) отмечен на северном окончании большого высокого языковидного останца из неогеновых глин с плоской верхушкой, расположенного в южной части оз. Кызылколь. Включает два крупных одиночных кургана с хорошо фиксируемыми рельефными склонами, стоящих отдельно непосредственно на кромке языкового останца, и четыре небольших насыпи, оформленных в цепочку, находящихся
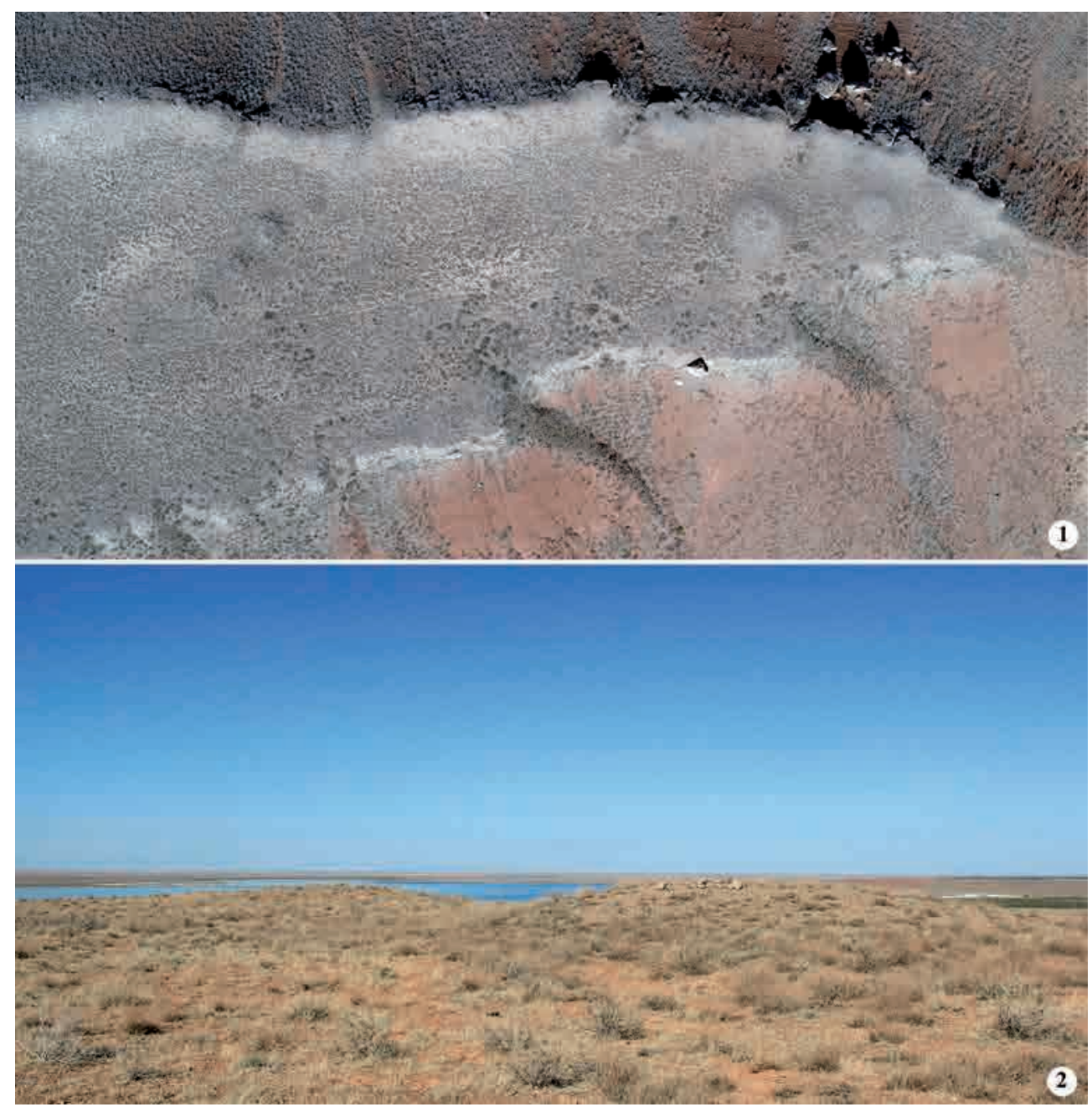

Рис. 5. Могильник Кыззылколь 4: 1 - вид сверху; 2 - насыпи

Fig. 5. Burial ground Kyzylkol 4: 1 - top view; 2 -embankments 
в 100 м к югу от больших курганов. Насыпи курганов сложены из камня, щебня и грунта, все они носят следы ограбления. Параметры крупных курганов: диаметр основания 20-22 м, высота 1,8 м; размеры малых курганов: диаметр основания 6-8 м, высота 0,6 м (рис. 1,$5 ; 5,1-2$ ).

Могильник Кызылколь 5 (7 курганов и 3 оградки). Курганы находятся по обе стороны неглубокого сухого сая, насыпи сложены из мелкого камня, щебня и грунта. Средние размеры курганов: диаметр основания 6-7 м, высота 0,5 м. Оградки прямоугольной формы размерами $1,2 \times 0,8$ м обозначены на поверхности камнямивалунами, среди которых встречены и поставленные вертикально отдельные небольшие плиты (рис. 1, 6).

Одиночные курганы (4 кургана) расположены на кромке высокой ле-
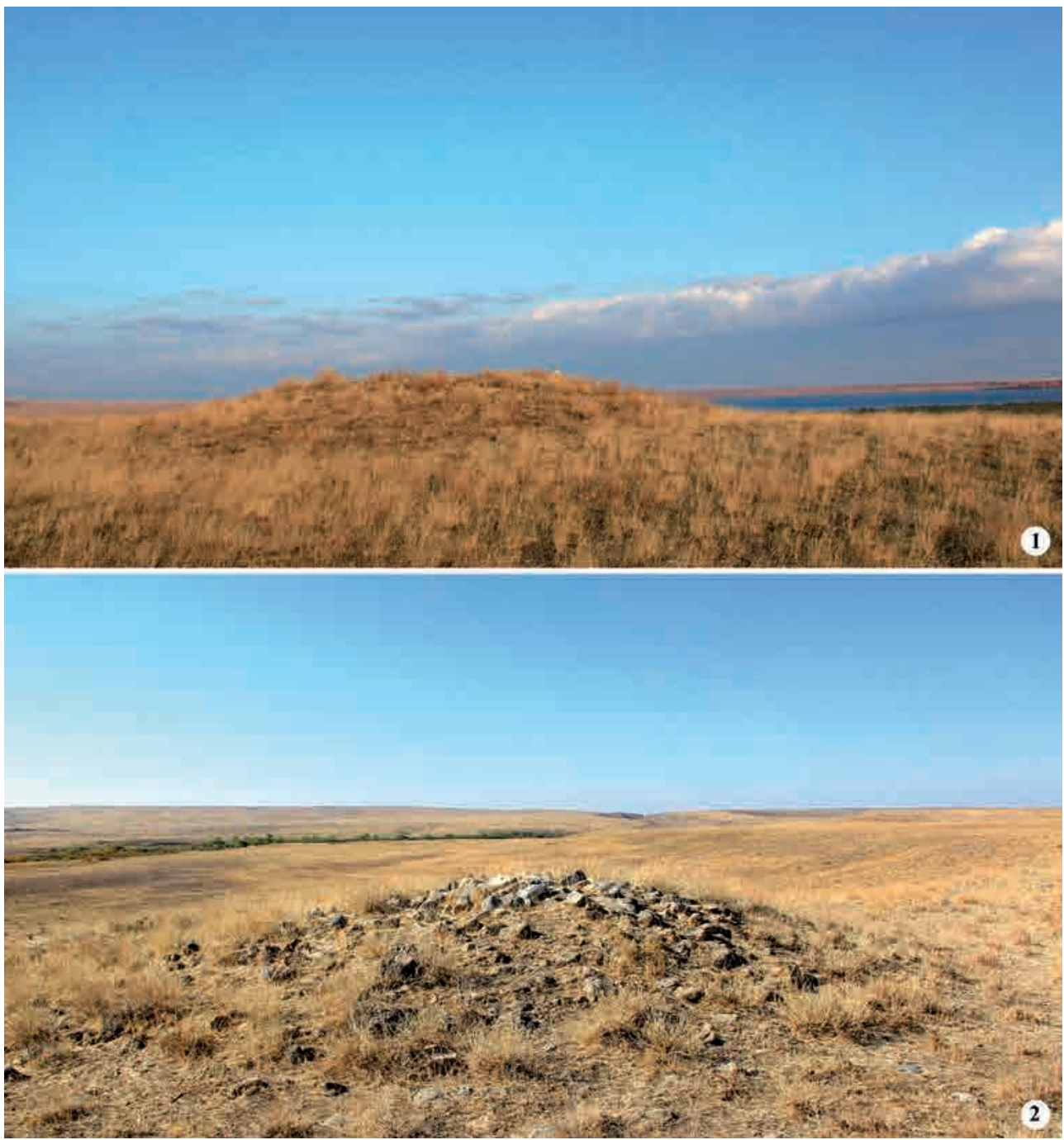

Рис. 6. Одиночные курганы на левой надпойменной террасе р. Ушбас: 1 - вид большой насыпи; 2 - вид средней насыпи

Fig. 6. Single mounds on the left floor terrace of the river Ushbas: 1 -view of a large embankment; 2 - view of the middle embankment 
вой надпойменной террасы р. Ушбас, недалеко от впадения последней в оз. Кызылколь (терраса имеет вид плоской платформы). Крупные насыпи курганов хорошо профилированы, выполнены из средних размеров каменных валунов, щебня и грунта. Параметры курганов: диаметр основания 18-23 м, высота 1,8 м (рис. 1, 7; $6,1-2)$.

Могильник Кьзылколь 6 (более 45 курганов) расположен вблизи п. Кызылколь, на длинном языковом останце с плоской платформой сверху из неогеновых глин длиной 4,5 км, который протянулся с северо-востока на юго-запад. Включает насыпи, сложенные из мелкого камня, щебня и грунта, оформленные в несколько цепочек. Средние размеры насыпей 5-7, 6-8, 9-10 м, высота 0,4-1 м.

Городище Актобе кызылкольское (рис. 1, 4). Топографически представляет собой трёхчастный объект, вытянутый по длинной оси в направлении СВ-Ю3, включающий:

- овально-прямоугольный в плане основной холм высотой 8-9 м с пологими склонами размерами в основании $110 \times 70 \times 104 \times 65$ м (шахристан);

- в верхней части шахристана отмечено также овально-прямоугольной формы возвышение размерами в основании 40×30 м, фиксируемое по периметру неглубокими рвами (цитадель);

- с юго-восточной стороны на расстоянии 120 м от главного холма (цитадель-шахристан) зафиксированы остатки, судя по всему, кольцевого рабада, который огибает памятник полукольцом длиной 210 м и шириной порядка 12-20 м;

- у юго-западного края основного холма городища зафиксировано отдельно стоящее здание правильной прямоугольной формы размерами $22 \times 15$ м с очертаниями прямоугольных помещений (рис. 7, 1-2).

Подъёмный материал с объекта включает мелкие фрагменты керамики от преимущественно столовой посуды (кувшины, кружки), а также орудия труда из камня, который предварительно можно датировать в пределах V-VI вв. (рис. 10, 1-16).

С целью выявления стратиграфии верхних культурных слоёв и получения археологического материала для хронологических и историкокультурных заключений на цитадели Актобе кызылкольское был заложен рекогносцировочный шурф размерами 2,8×2,4 м, который был доведён до глубины 1 м от уровня дневной поверхности. В площадь шурфа попала часть углового соединения пахсовой стены, судя по всему, прямоугольного в плане помещения верхнего строительного горизонта (южная часть шурфа) (рис. 8, 1); зафиксирован также глиняный пол, на котором отмечены зольники.

Разрез северной бровки рекогносцировочного шурфа демонстрирует следующую стратиграфию в последовательности «сверху - вниз»:

- верхний наносный лёссовый слой жёлтого цвета, не имеющий культурных напластований и артефактов $(0,38$ м) (рис. $8,2 a)$;

- насыщенный горизонтальный зольник почти чёрного цвета $(0,1 \mathrm{~m})$ (рис. 8, 2б);

- гумусно-зольниковый слой тёмно-серого цвета, в котором обнаружена основная масса артефактов (0,35 м) (рис. 8, 2в);

- зольниковый слой с включениями обломков пахсы, мелких костей, фрагментов керамики $(0,15$ м) (рис. 8, 22);

- прокалённый слой светлокоричневого цвета $(0,12$ м) (рис. $8,2 \partial)$.

Перечисленные напластования зафиксированы в правой стороне разреза северной бровки; на левой стороне разреза по всей высоте отмечены светло-жёлтые слои глины, спорадически видны гумусно-зольниковые вкрапления светло-серого цвета, и следы деятельности грызунов (рис. 8, 2e). 

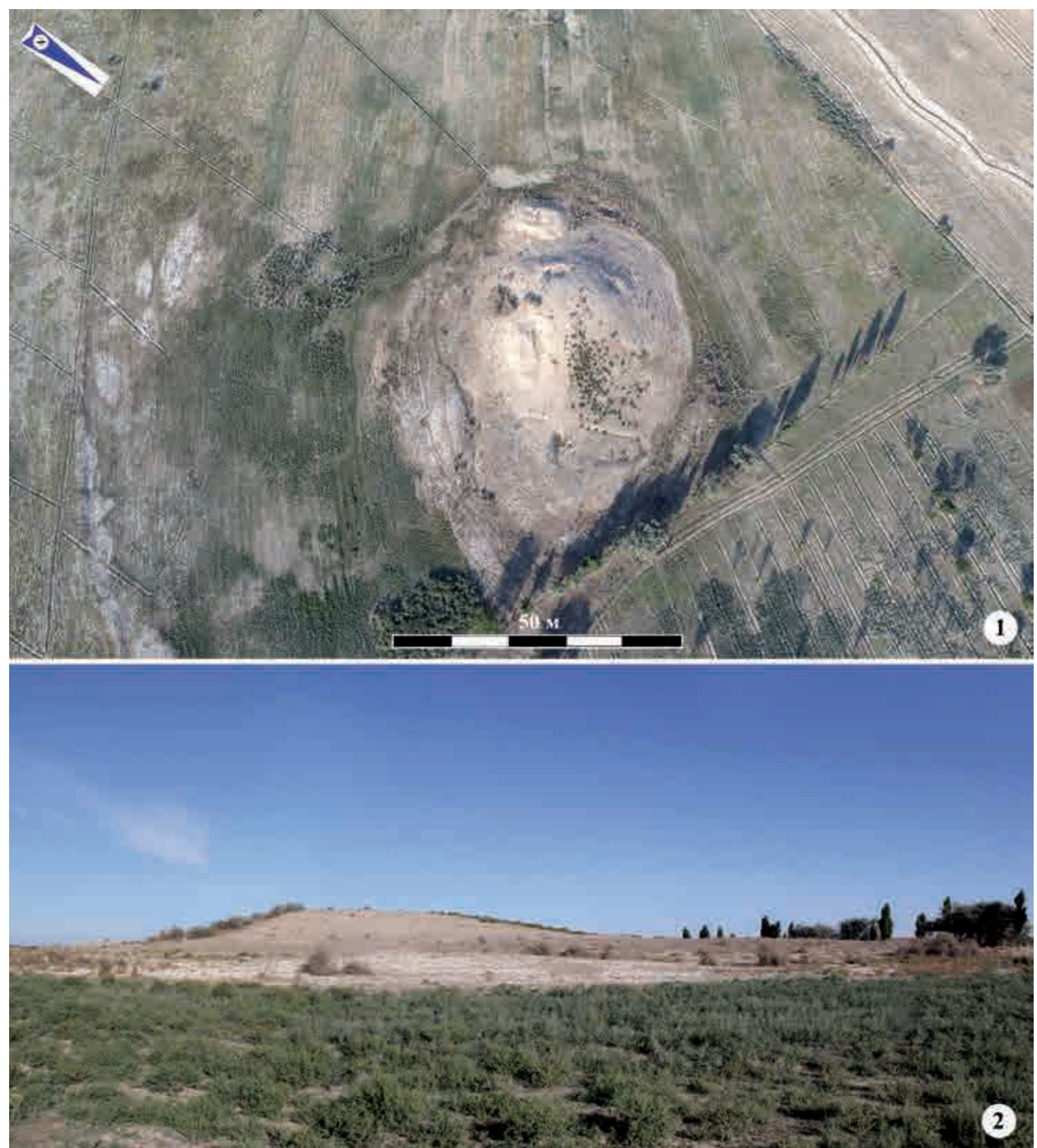

Рис. 7. Городище Актобе кызылкольское: 1 - вид сверху; 2 - общий вид

Fig. 7. Settlement Kyuzylkol Aktobe: 1 - top view; 2 -general view

В ходе работ был получен археологический материал (керамика, каменные орудия), часть которого даёт информацию для предварительных хронологических и историкокультурных заключений. В частности, это керамика хозяйственно-бытового, столового и кухонного назначения (в основном фрагментарная), в числе которой заслуживают внимания:

- венчик хумчи, покрытый светло-коричневым ангобом, поверх которого имеются ангобные потёки более тёмного цвета и кисточкой нанесён тамгообразный знак (рис. 9, 1);

- горловина и верхняя часть тулова крупной фляги (украшена светлосерым и потёками светло-коричневого ангоба) (рис. 9, 2);

- части горловин от столовых кувшинов. Сосуды имеют под венчиком выраженный концентрический рельефный каннелюр, они украшены станковым рифлением, покрыты ангобом тёмно-коричневого, тёмно-серого цветов (рис. 9, 3, 4, 6, 7, 10, 13); не- 


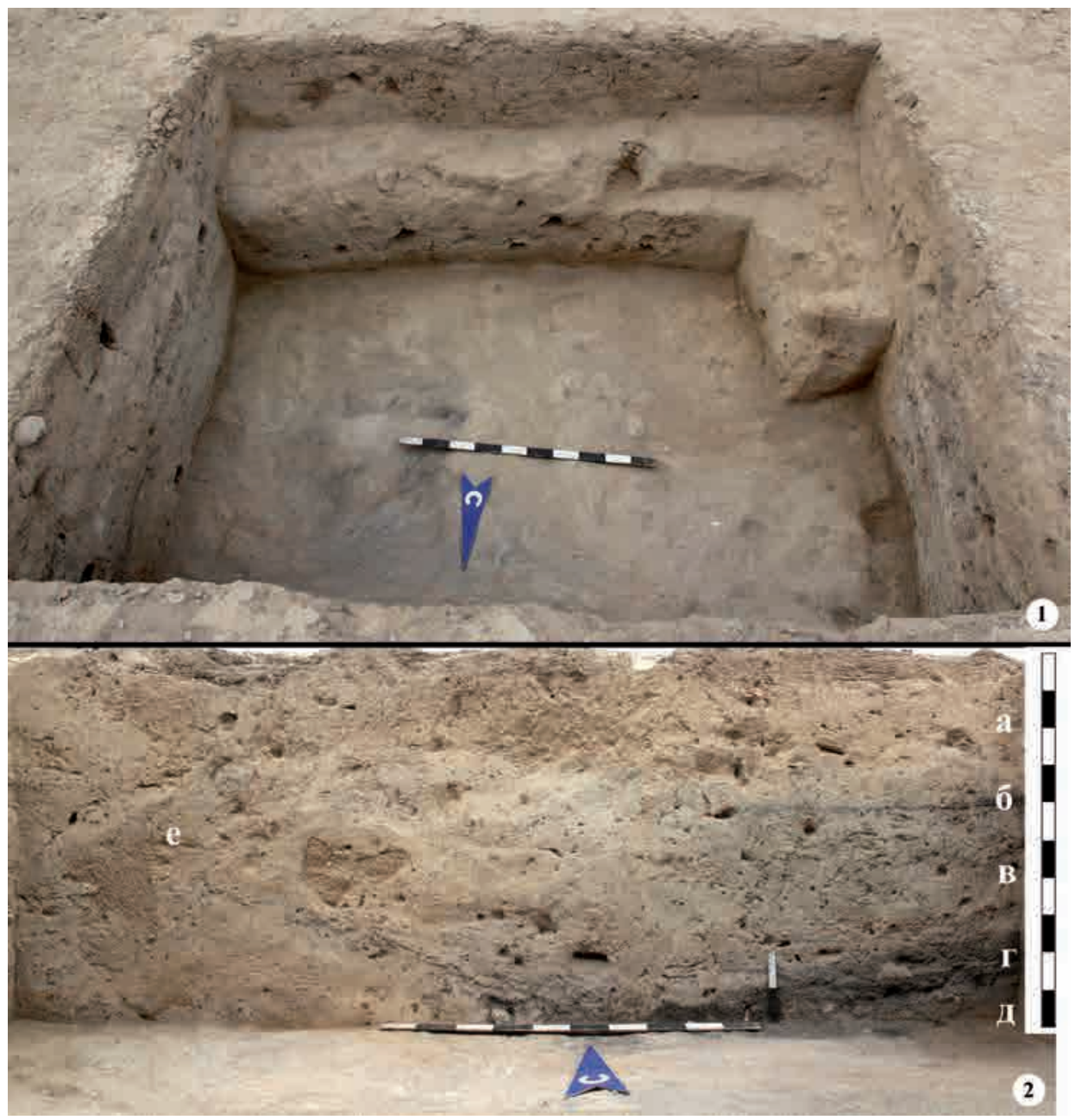

Рис. 8. Городище Актобе кызылкольское. Рекогносцировочный шурф: 1 - обший вид; 2 - разрез

Fig. 8. The settlement of Kyzylkol Aktobe. Reconnaissance pit: 1 - general view; 2 - section

которые сосуды имели вертикальные петлевидные ручки (рис. 9, 14);

- фрагмент венчика от столового горшка; покрыт ангобом краснокоричневого цвета и залощён (рис. 9, 5);

- венчики и части тулова с основаниями ручки от столовых кружек. Кружки покрывались краснокоричневым ангобом, украшались вдавленными круглыми пунсонами (рис. 9, 8-9, 12);

- миниатюрная плошка с невысоким бортиком со следами использования на открытом огне (рис. 9, 11). 130
В контексте историкокультурного происхождения и хронологии определённый интерес представляет и подъёмный материал с городища Актобе кызылкольское. Речь идёт о таких керамических изделиях, как напрясла (пряслица) (рис. 10, 4) и заготовки к ним (рис. 10,1-3), а также декор некоторых видов посуды: станковое рифление (рис. 10, 8-11); ангобные потёки (рис. 10, 12, 13-15), прочерченное рифление (рис. 10, 16), прямоугольное с отверстием каменное навершие, судя по всему, для черешкового бытового ножа (рис. 10, 5). 


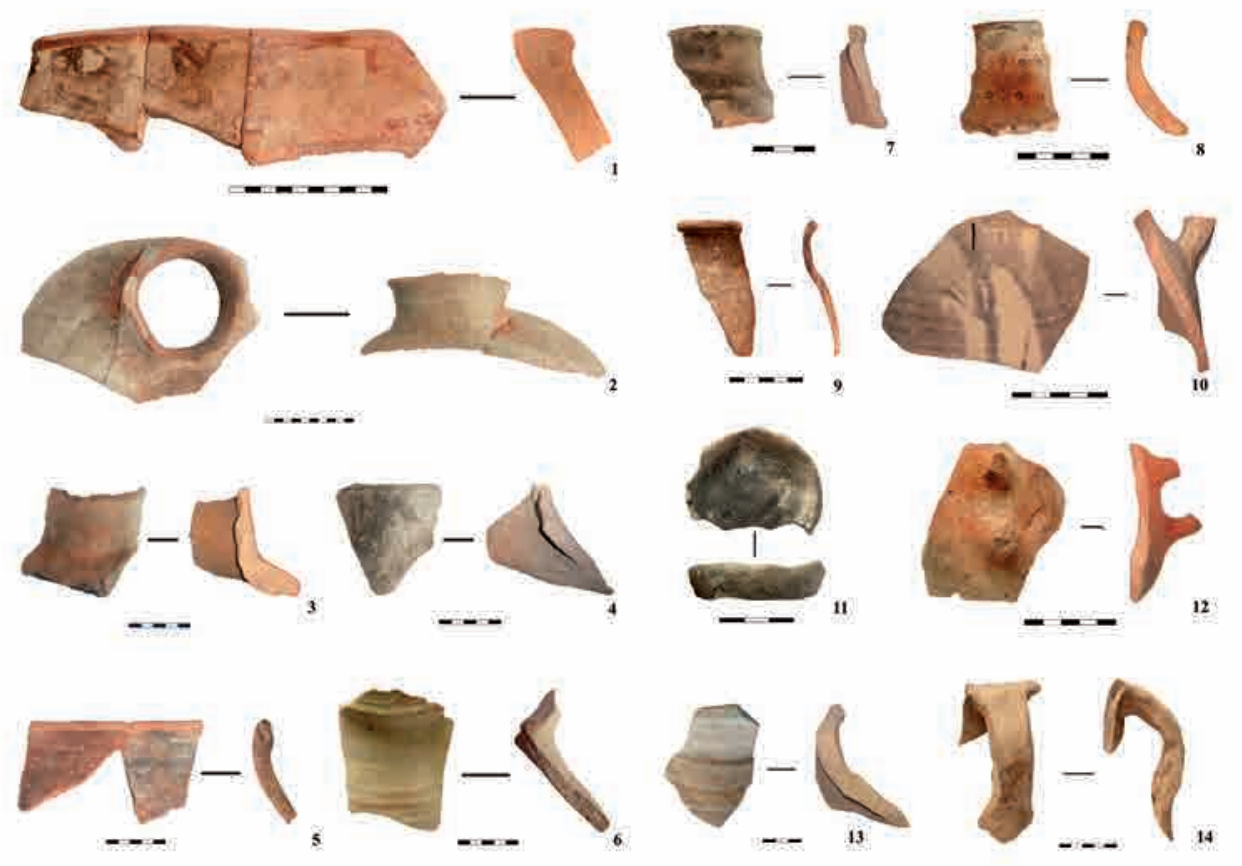

Рис. 9. Городище Актобе кызылкольское. Керамический комплекс из рекогносиировочного шурфа и подъёмного материала

Fig. 9. The settlement of Kyzylkol Aktobe. Ceramic complex of reconnaissance pit and lifting material

Каменное сооружение на холме Кьзылсенгир

Это сооружение находится наверху правильного конусовидного останца из материковых неогеновых глин красного цвета, лишённых всяких культурных отложений. Параметры конуса: диаметр основания 200-240 м, высота 18-20 м (рис. 12, 2). В верхней части конуса чётко фиксируется искусственно сложенная платформа-стилобат из глин другого происхождения и цвета размерами $30 \times 22$ м и высотой порядка 2-2,5 м, на которой расположено прямоугольное в плане сооружение из каменных стен размерами $17 \times 15$ м при сохранившейся высоте около 0,5-0,7 м. По этой причине верхняя часть конуса Кызылсенгир имеет трёхступенчатый вид в разрезе, напоминающий классический зиккурат. Значительное количество каменных валунов из кладки верхнего контура стен осыпалось на склоны холма, однако общая прямоугольная планировка здания, как и треугольное предвратное сооружение с северной стороны, фиксируется очень хорошо (рис. 12, 1).

Склоны материкового холмаконуса плавные, но достаточно крутые, порядка $30-32^{\circ}$, они все усеяны тысячами мелких фрагментов самой разнообразной по назначению, размерам и декору керамики (от хумов, тагара, горшков, кувшинов, чаш - до косметических сосудиков), а также разбитыми частями каменных жерновов, ладьевидных зернотёрок, тёрок и маленьких тёрочек, оселков-кайраков, иных функциональных камней, круглых грузил и т.п. (найден также бронзовый браслет - рис. 14, 3).

Собранный со склонов материкового холма-конуса подъёмный ма- 
териал представлен следующими значимыми артефактами:

- фрагментами каменных орудий труда: круглые жернова из песчаника и гранита с отверстием в центре и функциональной поверхностью с бороздами (рис. 15, 1);

- ладьевидные зернотёрки с характерной выработанной рабочей поверхностью (рис. 15, 2); одна зернотёрка имеет полировку всех сторон (рис. 15, 3);

- тёрочники к зернотёркам различной формы (рис. 15, $6,7)$;

- грузила окру-

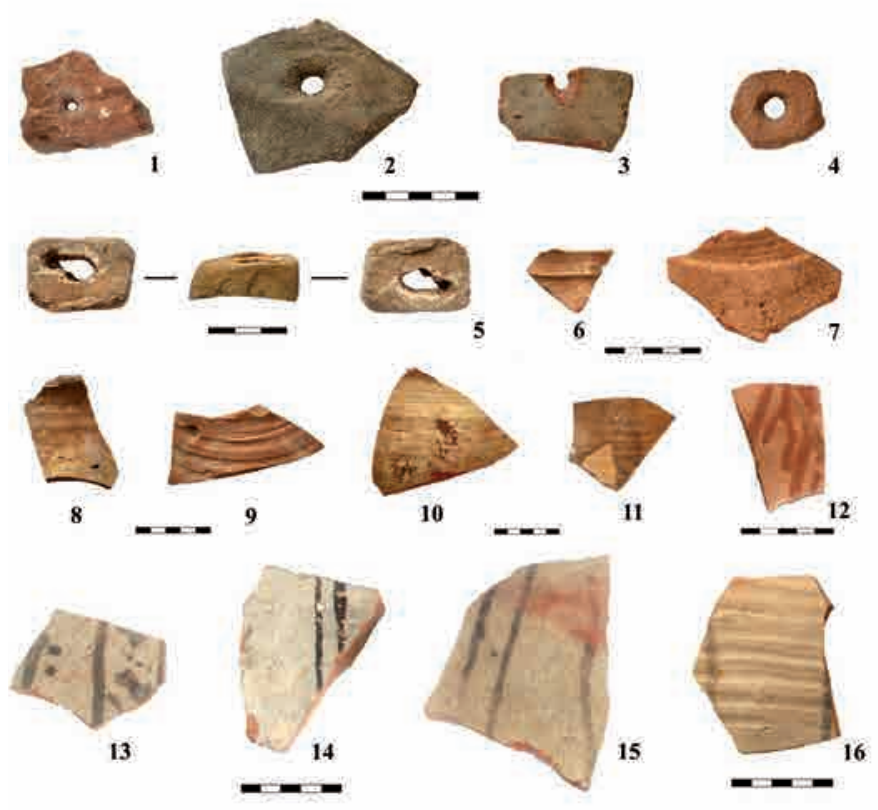

Рис. 10. Городище Актобе кызылкольское.

Варианты декора керамической посуды

Fig. 10. The settlement of Kyzylkol Aktobe.

Ceramic dishes decor options

глые с отверстием в центре (рис. 15, 4, 5);

- каменное многофункциональное лощило с четырьмя рабочими гранями (рис. 11, 8).

Получен также выразительный керамический подъёмный материал, который характеризуют следующие фрагменты от сосудов различного функционального назначения:

- горизонтальные зооморфные ручки с выступами от кухонных горшков (котлов), имитирующих рога животных (рис. 16, 1, 3);

- зооморфный декор в районе крепления оснований ручек сосудов (в верхней и нижней частях) в виде изображений головы архара, завитков рогов, выступов в верхней части ручки, а также частей тела других животных (рис. 16, 2, 4-б);

- антропоморфное изображение на стенке сосуда с выраженными мужскими половыми признаками (рис. 16, 9);

- рельефно-выпуклые тамгообразные знаки подковообразной и стреловидной формы (в том числе парные; рис. 16, 5, 12-14).

- прочерченные знаки в виде вертикальных линий на ручках (рис. 16, 7, 8).

С целью выявления стратиграфии верхних культурных напластований и получения археологического материала во внутреннем пространстве каменного сооружения, в южной его стороне, был заложен рекогносцировочный шурф размерами $1,6 \times 1,8 \mathrm{M}$, который был доведён до глубины 1,3 м от уровня дневной поверхности (рис. 13, 1). В результате в северовосточной части шурфа была зафиксирована стационарная стена, сложенная из камня, которая, видимо, является частью внутренней застройки (рис. $13,1 a$ ), а на уровне пола шурфа в юго-западной его части зафиксиро- 


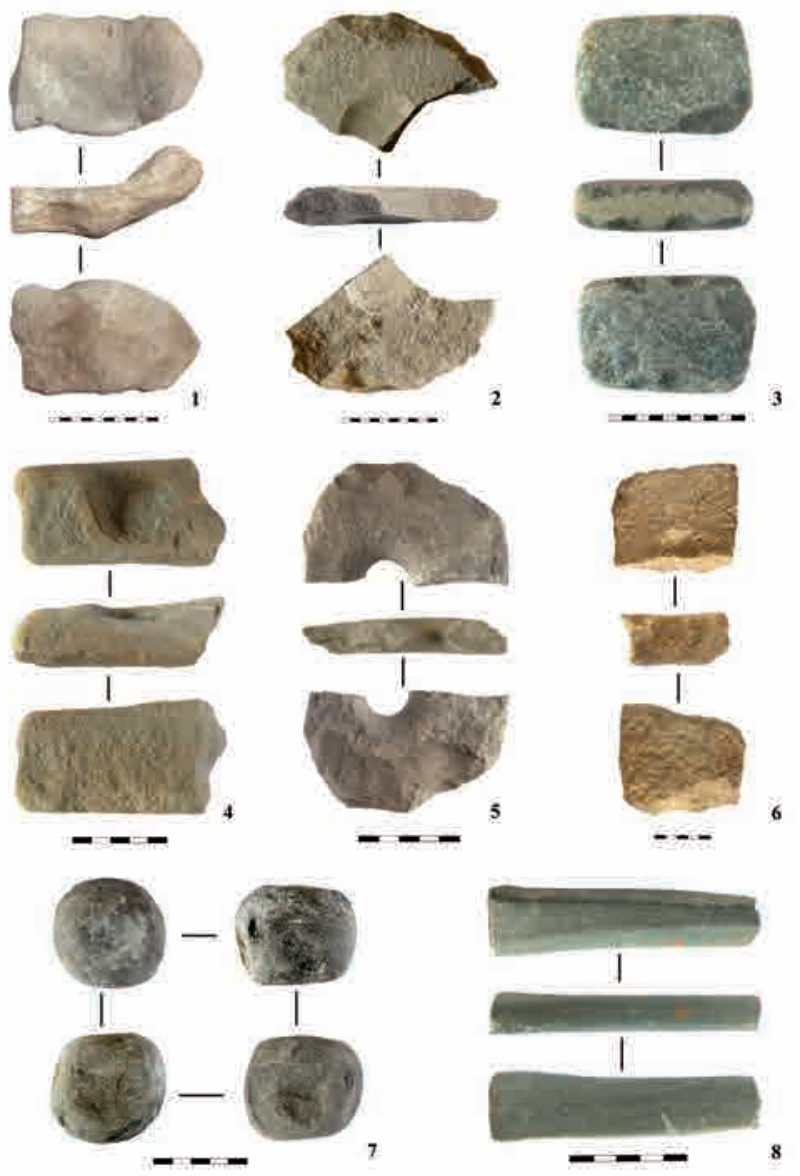

Рис. 11. Орудия труда из камня

Fig. 11. Tools made of stone

слои насыщены большим количеством зольников, мелких углей, здесь сосредоточены целые формы сосудов и многочисленные фрагменты керамики, которые все носят следы использования на открытом огне.

В частности, здесь в северо-восточном углу шурфа обнаружен сильно обгоревший столовый кувшин (форма восстанавливается), а также абсолютно целый и готовый к использованию миниатюрный керамический тигель для выплавки драгоценных металлов (золото, серебро; рис. 13, 1в, 12; 14, 1, 2). Кроме всего, здесь же обнаружены фрагменты кухонной посуды с рельефновыпуклыми подковообразными знакамитамгами (рис. 14, 4-6).

Обсуждение материалов и выводы

Вопрос функционального предназначения каменного сооруже-

ваны мощные горизонтальные многослойные зольники (рис. 13, 1б).

Разрезы и фиксация стратиграфии всех бровок рекогносцировочного шурфа представлены на рисунке 13 (рис. 13, 2-5) и демонстрируют следующую закономерность: верхние напластования, до 0,6-0,7 м толщиной, являются практически стерильными в культурном контексте, в них эпизодически встречаются мелкие фрагменты керамики и отмечены только крупные камни, из которых выложены внутренние стены каменного сооружения. В противоположность нижние ния на сопке Кызылсенгир остаётся ства, как масса битой керамики, каменных орудий труда (ритуал намеренного «уничтожения»), множество зольников и напластований из сгоревшего органического топлива внутри объекта, а также находка керамического тигля для выплавки золота, позволяют предварительно трактовать его как храм-святилище, имеющий отношение, скорее всего, к зороастризму. 


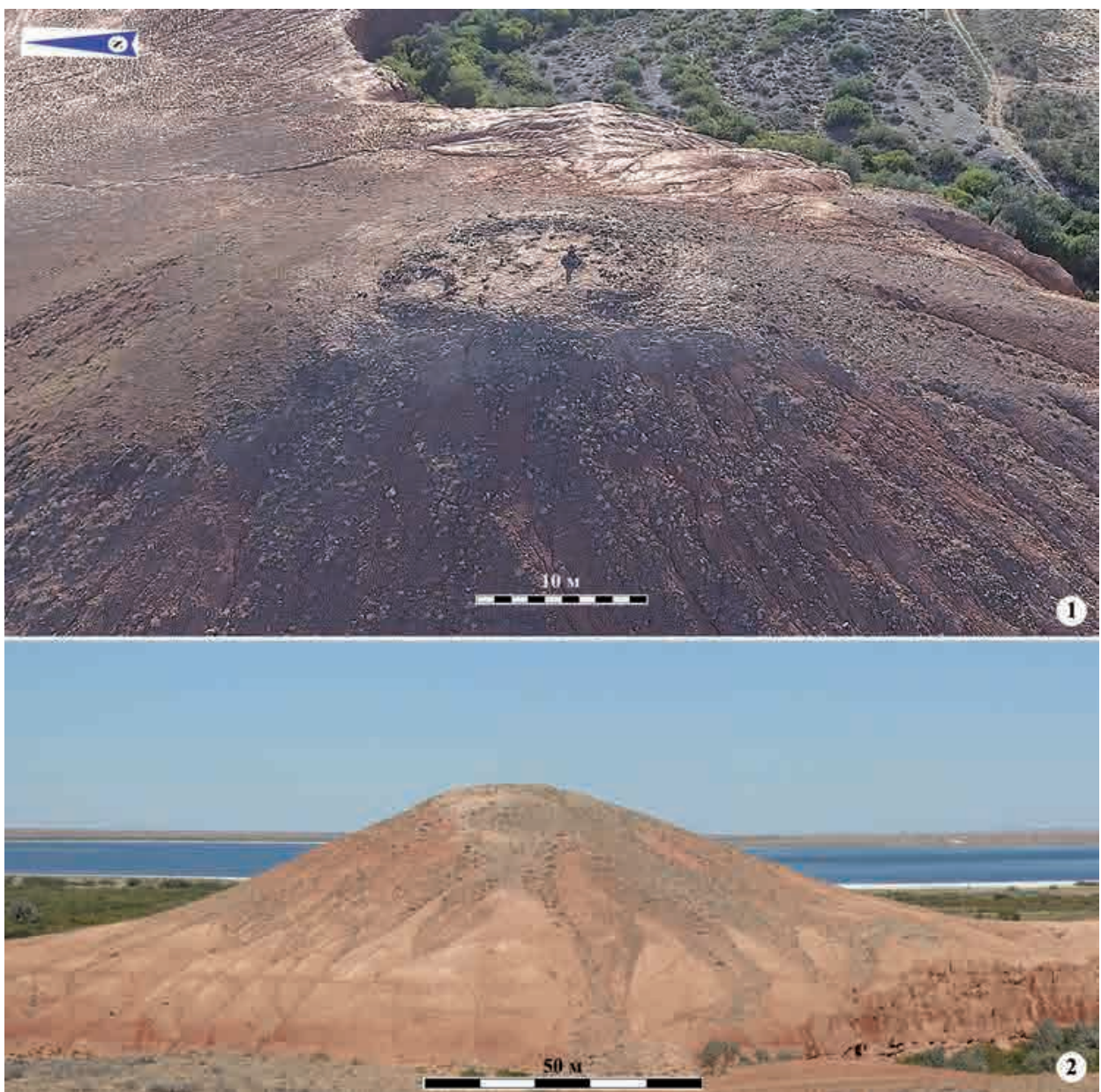

Рис. 12. Каменное сооружение на холме Кызылсенгир: 1 - вид сверху; 2 - общий вид

Fig 12. Stone structure on Kyzylsengir hill: 1 -top view; 2 - general view

Отметим, что археологические материалы городища Актобе кызылкольское и каменного сооружения Кызылсенгир по ряду параметров (керамика и приёмы декора, каменный инвентарь, знаки-тамги) тесным образом перекликаются, демонстрируют историко-культурное единство и временную синхронность, в том числе - с опорным крупным центром государства Кангюй I-IV вв. городищем Ушбастобе в Угамской долине [Подушкин А.Н., 2019, с. 165, рис. 1, 1-13].

Остановимся на вопросах хронологии. В качестве уверенных хро- ноиндикаторов, полученных при раскопах на двух объектах, выступают керамический комплекс, каменные орудия труда, характер декора сосудов, тамгообразные знаки и антропоморфное изображение. Например, перечисленные выше формы сосудов, приёмы декора (особенно станковое рифление, рельефно-выпуклые концентрические каннелюры под венчиком кувшинов, покрытие коричнево-красным ангобом и его потёками), наличие знаков на керамике прямо перекликается с керамикой арысской культуры Южного Казахстана (конец второго карато- 


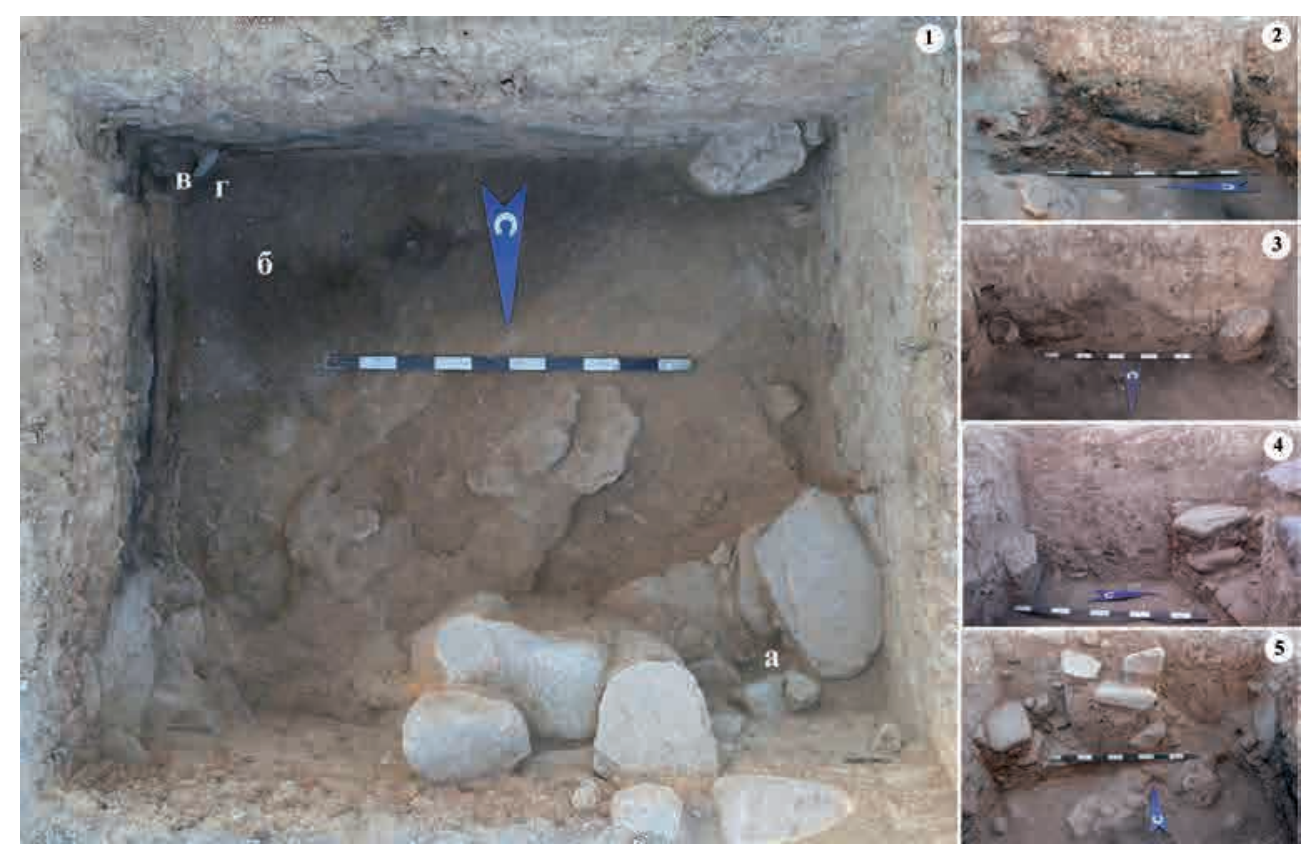

Рис. 13. Рекогносиировочный шурф на каменном сооружении Кызылсенгир: 1 - вид сверху; 2-4 - стратиграфические разрезы

Fig. 13. Reconnaissance pit at the Kyzylsengir stone structure: 1-top view; 2-4-stratigraphic sections

бинского этапа) периода государства Кангюй III-IV вв. [Подушкин А.Н., 2000, с. 116; рис. на с. 106-108]; прочерченное рифление как декор отмечено в могильнике Шага [Максимова, 1974 , с. $102-103$, рис. 10,2$]$

В контексте хронологических и историко-культурных заключений интересен набор каменных орудий труда, часть которого получена при сборе подъёмного материала (рис. 11, 1-5), а часть происходит из рекогносцировочного шурфа (рис. 11, 6-8). Так, ладьевидные зернотёрки, тёрочники к ним, тёрочки-ступки, а также круглые каменные грузила с отверстием в центре встречены в материалах поселения Караултобе I-IV вв. [Подушкин Н.П., 1974 , с. 81, табл. I, 1, 2, 5-18]; аналогичные зернотёрки и каменные грузила встречены на поселении Актобе баба-атинском III-IV вв. [Сенигова, 1962 , с. 78 , рис. 19,1 ; рис. $20,1,2$, 4-8]. Каменные жернова и ладьевидные зернотёрки, подобные кызылкольским, имеются в материалах усадьбы Кайрагач первой половины I тыс. н.э. из юго-западной Ферганы [Брыкина, 1982, с. 84, табл. 39, 3-7].

Заслуживает внимания также антропоморфное изображение из каменного сооружения Кызылсенгир, аналогии которому отмечены в материалах джетыасарской культуры низовьев Сырдарьи II-IV вв. [Левина, Чижова, 1995, с. 187, рис. 2, 8, 9].

Корреляция приведённых выше аналогий и хронологических выкладок позволяют отнести новые археологические материалы из рекогносцировочных раскопок городища Актобе кызылкольское и каменного сооруже- 


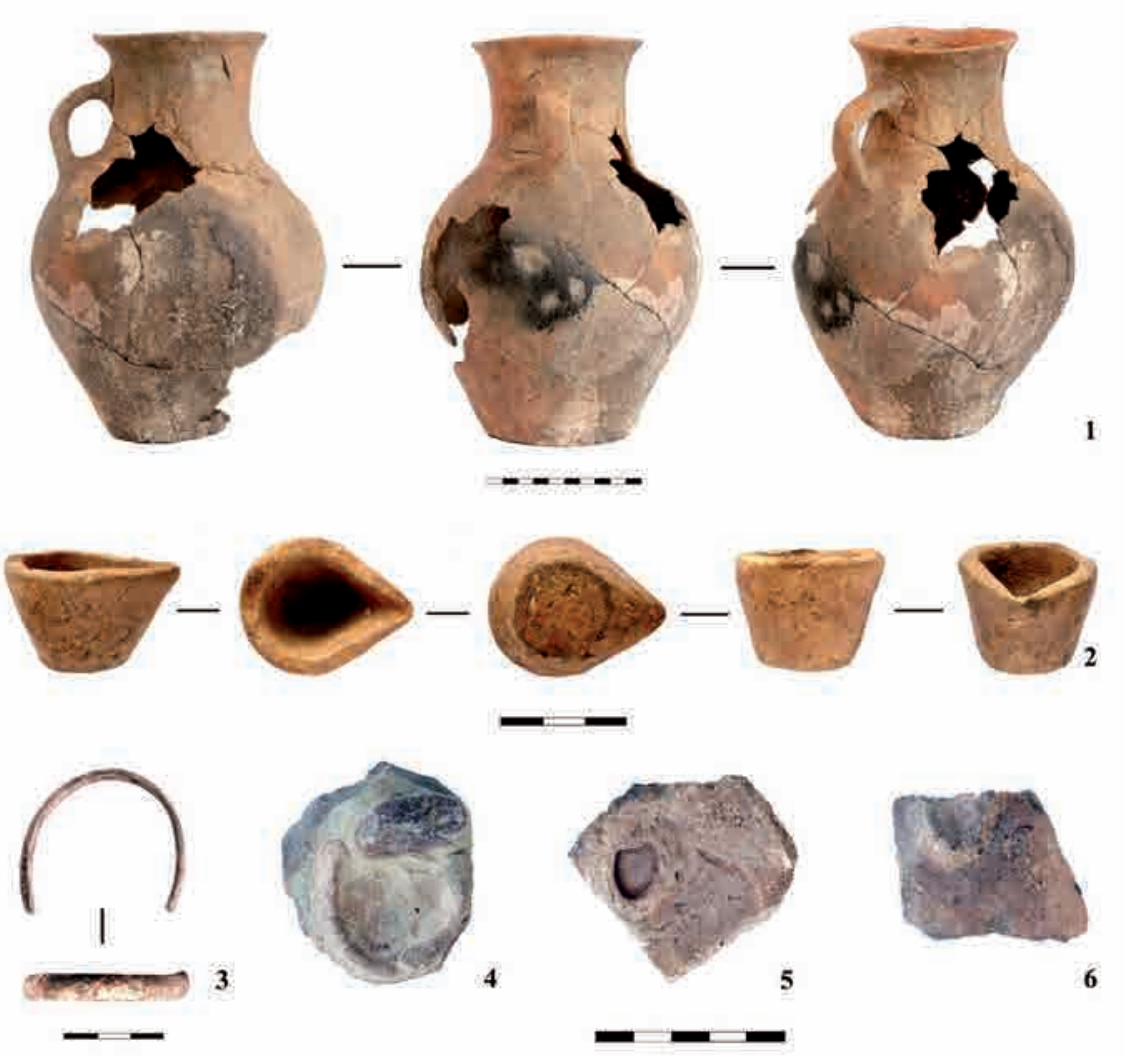

Рис. 14. Артефакты из рекогносцировочного шурфа на каменном сооружении холма Кызылсенгир: 1 - керамический столовый кувшин; 2 - керамический тигель для выплавки драгоиенных металлов; 3 - бронзовый браслет; 4-6- ррагменты керамики с тамгообразныли знаками

Fig. 14. Artifacts from reconnaissance pit on the stone structure of the Kyzylsengir hill: 1 -ceramic jug; 2 -ceramic crucible for precious metals smelting; 3 - bronze bracelet; 4-6-fragments of ceramics with tamga-shaped signs

ния Кызылсенгир КИКЗ ко времени I-III, возможно IV-V вв. н.э., а в этнокультурном плане уверенно связать их с арысской культурой Южного Казахстана, отражающей устойчивые системы традиций в материальной сфере государства Кангюй.

В завершение выводов о первоначальном изучении памятников археологии КИКЗ, подчеркнем одно обстоятельство, иллюстрирующее высокую значимость последующих научных изысканий в этом регионе: аэрофотосъемка квадрокоптером выявила ещё один немаловажный элемент, который представляет собой две параллельные гравийные и каменные отсыпки длиной около 300 м при ширине от 6-8 м (вместе с разделительным пространством), фиксируемые в направлении восток-запад от городища Актобе кызылкольское вблизи курганного поля могильника Кызылколь 1 (западная группа насыпей) к каменному сооружению на сопке Кызылсенгир (рис. 17). 


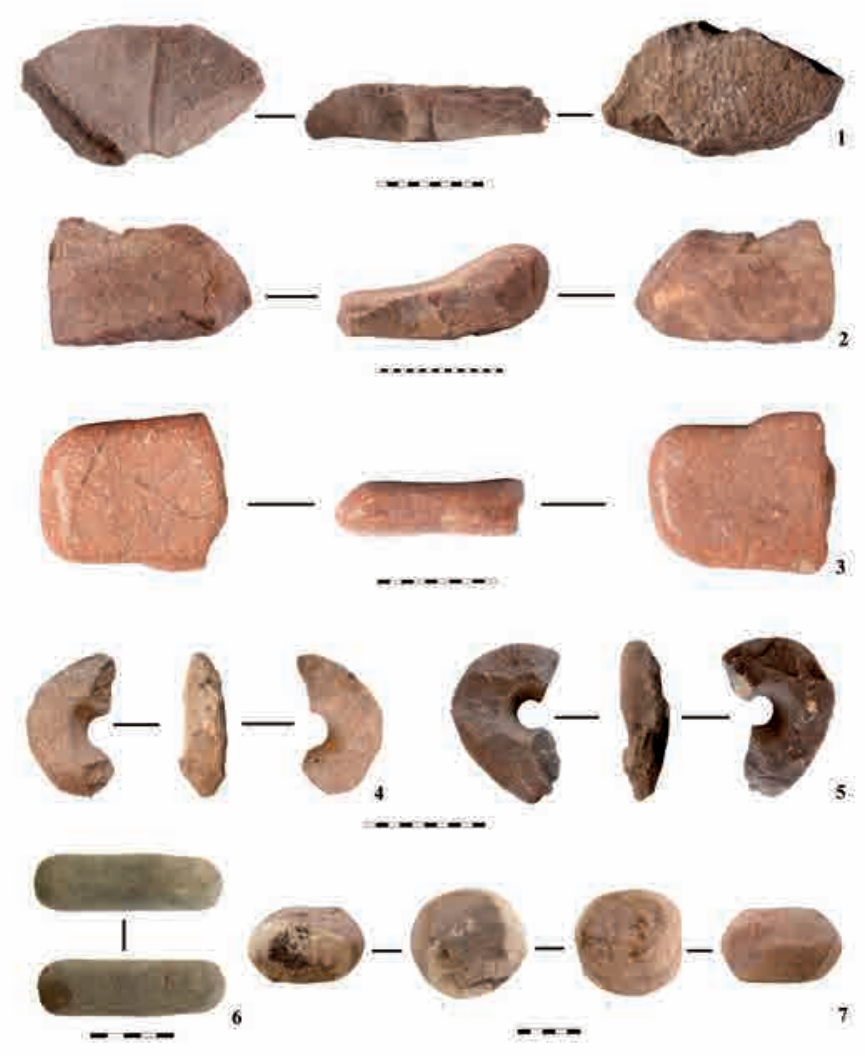

Рис. 15. Каменное сооружение на холме Кызылсенгир. Подъёмный материал: 1 - ррагмент жернова; 2, 3- ррагменты зернотёрок; 4, 5-фрагменты грузил; 6, 7 - тёрочники. 1-7-камень

Fig. 15. Stone structure on Kyzylsengir hill. Lifting material: 1 -fragment of millstone;

2, 3-fragments of grains; 4, 5-fragments of weights; 6, 7-pestles, 1-7-stone

Судя по всему, учитывая связывающую функцию и контекст «началоконец», это дорога (путь) от городища («местожительство» с отдельно стоящим прямоугольным сооружением, возможно, культового назначения), у «могил предков» в виде курганных насыпей, к храму-святилищу (рис. 17).

Анализ иных составляющих (особенно в плане некоторых представлений зороастрийского содержания: «Мировая Гора», «Священная Вода», культ фарн-хварна у кангюйцев в воплощении архара или че- ловека), красный цветосимволизм основания холма Кызылсенгир (символ огня, солнца, золота), ритуальное уничтожение почти всех предметов, имеющих причастность к земледельческому способу хозяйствования, в ходе «огненного» действия внутри каменного сооружения, не оставляют сомнений в том, что мы имеем дело с уникальным культовым центром государства Кангюй.

Археологический и историкокультурный потенциал работ в КИКЗ объективно значителен, об этом свиде- 


\section{ҚАЗАҚСТАН АРХЕОЛОГИЯСЫ № 2 (12) 2021}

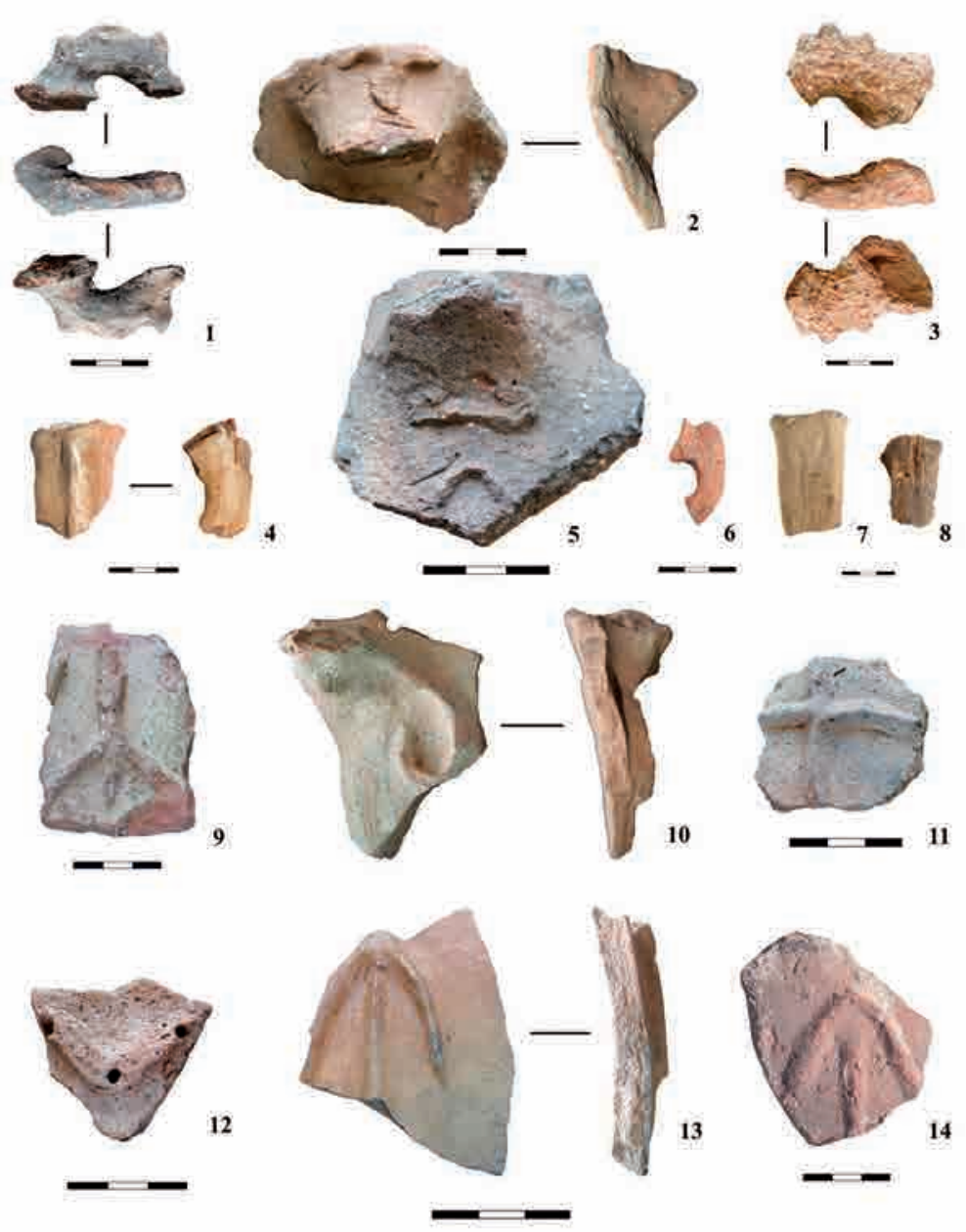

Рис. 16. Каменное сооружение на холме Кызылсенгир. Керамика: 1, 3 - зооморфные горизонтальные ручки; 2, 5, 10 -мотивы, связанные с образом барана;

6- зооморфный налеп в верхней части ручки; 7, 8, 11-14- тамгообразные знаки

Fig. 16. Stone structure on Kyzylsengir hill. Ceramics: 1, 3-zoomorphic horizontal handles; 2, 5, 10 -motives related to the image of the ram; 6-zoomorphic patch at the top of the handle; 7, 8, 11-14-tamga-shaped signs

тельствует уже полученный материал, исчисляемый множеством артефактов только с двух объектов. С началом исследований памятников в КИКЗ можно констатировать, что фактически речь идёт о научном и историкокультурном освоении нового региона, ранее не изученного, особенно - в контексте периода истории, связанного с поздним государством Кангюй, эфталитами («белые сюнну»), возможно - тюрками и согдийцами. 
Подушкин А.Н., Донец А.Г. Исследование памятников археологии в урочище Кызылколь

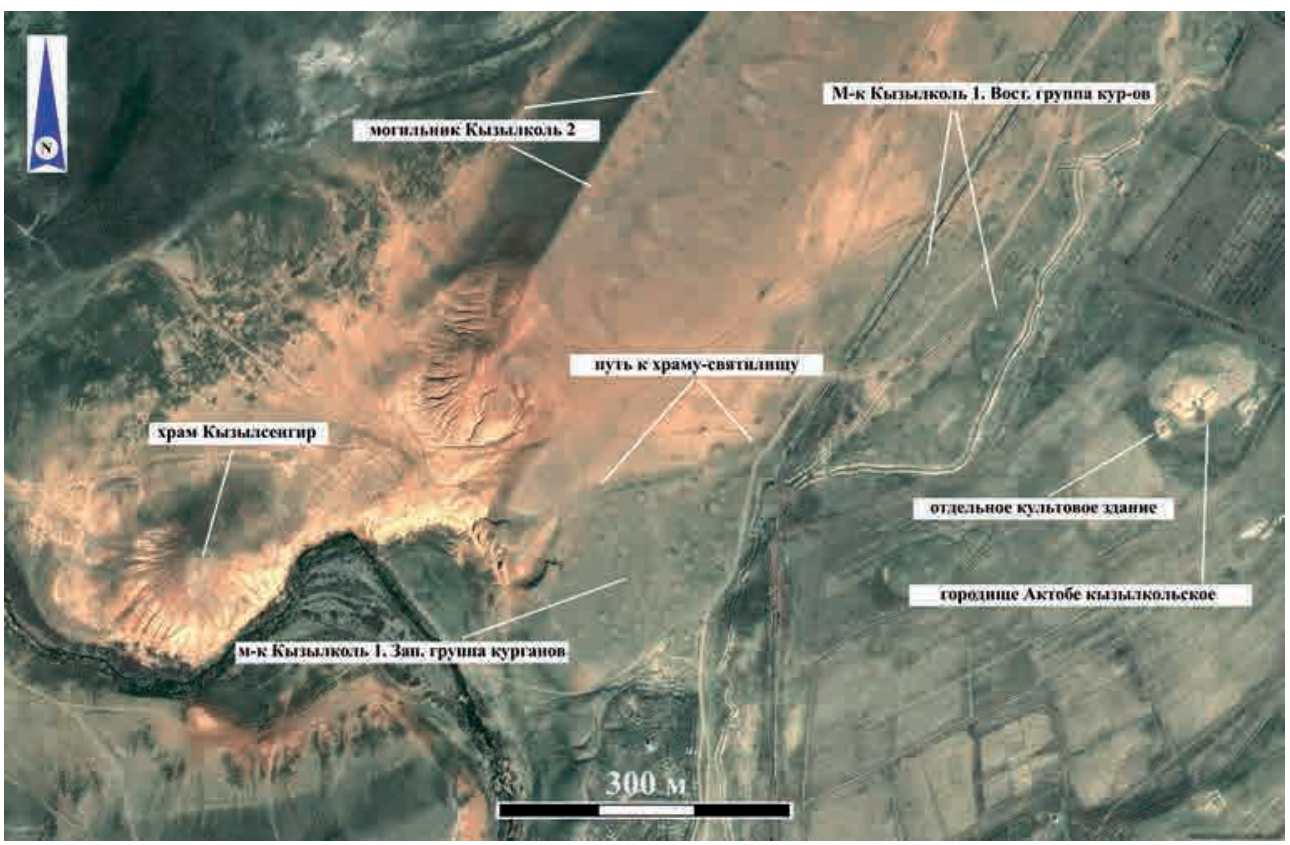

Рис. 17. Кызылкольская историко-культурная зона. Маркировка памятников культового иентра государства Кангюй (вид сверху)

Fig. 17. Kyzylkol historical and cultural zone. Marking of monuments of the cult center of Kangju state (top view)

\section{ЛИТЕРАТУРА}

1. Агеева Е.И. Краткие итоги работ археологических экспедиций Института истории, археологии и этнографии 1953 года // Известия АН КазССР. Сер. истории, экономики, философии и права. 1954. № 137, вып. 1. С. 83-86.

2. АКК. Археологическая карта Казахстана. Реестр / Е.И. Агеева, К.А. Акишев, Г.А. Кушаев и др. (сост.). Алма-Ата: Изд-во АН КазССР, 1960. 449 с.

3. Брыкина Г.А. Юго-Западная Фергана в первой половине I тысячелетия нашей эры. М.: Наука, 1982. 196 с.

4. Левина Л.М, Чижова Л.В. О некоторых зооморфных и антропоморфных изображениях в джетыасарской культуре // Низовья Сыр-Дарьи в древности: джетыасарская культура. М.: Институт этнологии и антропологии им. Н.Н. МиклухоМаклая, 1995. Вып. V, ч. 5. С. 185-201.

5. Максимова А.Г. Гробницы типа науса у с. Чага (Шага) // В глубь веков / отв. ред. К.А. Акишев. Алма-Ата: изд-во «Наука» КазССР, 1974. С. 95-118.

6. Подушкин А.Н. Государство Кангюй в свете новых археологических, палеолингвистических и нумизматических данных // Древности Восточной Европы, Центральной Азии и Южной Сибири в контексте связей и взаимодействий в евразийском культурном пространстве (новые данные и концепции): м-лы междунар. конф. (г. СПб, 18-22 ноября 2019 г.). СПб.: ИИМК РАН, 2019. Т. І. С. 165-168.

7. Подушкин А.Н. Арысская культура Южного Казахстана IV в. до н.э. - VI в. н.э. Туркестан: изд-во МКТУ им. Х.А. Ясави, 2000. 202 с.

8. Подушкин А.Н. Николай Павлович Подушкин - учёный, археолог, человек (к 90-летию со дня рождения) // Археология Казахстана. 2019. № 3 (5). С. 24-36.

9. Подушкин Н.П. О хозяйстве оседлого населения Арыси в I - IV вв. н.э. // В глубь веков / отв. ред. К.А. Акишев. Алма-Ата: изд-во «Наука» КазССР, 1974. C. 78-84. 
10. Свод памятников истории и культуры Казахстана. Южно-Казахстанская область. Алматы: «Қазақ энциклопедиясы», 1994. 367 с. C. 57-82.

11. Сенигова Т.Н. Поселение Актобе // ТИИАЭ АН КазССР. 1962. Т. 14.

12. Сенигова Т.Н., Мерщиев М.С., Максимова А.Г. Археологические исследования на северных склонах Каратау // ТИИАЭ АН КазССР. 1962. Т. 14. С. 57-116.

\section{REFERENCES}

1. Ageeva, E. I. 1954. In: Izvestiya AN KazSSR. Ser. istorii, ekonomiki, filosofii i prava (News of the Academy of Sciences of the Kazakh SSR. Ser. history, economics, philosophy and law), 137, 1, 83-86. (in Russian).

2.Ageeva, E. I., Akishev, K. A., Kushaev, G.A. et al. (compl.). 1960. Arheologicheskaya karta Kazahstana (Archaeological map of Kazakhstan). Register. Alma-Ata: Academy of Sciences of the Kazakh SSR Publ. (in Russian).

3. Brykina, G. A. 1982. Yugo-Zapadnaya Fergana v pervoy polovine I tysyacheletiya nashey ery (Southwest Fergana in the first half of the 1st millennium AD). Moscow: "Nauka" Publ. (in Russian).

4. Levina, L. M, Chizhova, L. V. 1995. In: Nizoviya Syr-Darii v drevnosti: dzhetyasarskaya kultura (Lower Syr-Darya in antiquity: Jetyasar culture). Moscow: N.N. Miklouho-Maclay Institute of Ethnology and Anthropology, 185-201 (in Russian).

5. Maksimova, A. G. 1974. In: Akishev, K. A. (ed.). V glub vekov (Into the depths of the centuries). Alma-Ata: "Nauka" Publ., 95-118 (in Russian).

6. Podushkin, A. N. 2019. In: Drevnosti Vostochnoy Evropy, Centralnoy Azii i Yuzhnoy Sibiri $v$ kontekste svyazey $i$ vzaimodeystviy $v$ evraziyskom kulturnom prostranstve (novye dannye i koncepcii) (Antiquities of East Europe, South Asia and South Siberia in the context of connections and interactions within the Eurasian cultural space (new data and concepts)), 1. Saint Petersburg: Institute for the history of material culture RAS, 165-168 (in Russian).

7. Podushkin, A. N. 2000. Arysskaya kultura Yuzhnogo Kazahstana IV v. do n.e. - VI v. n.e. (Arys culture of South Kazakhstan $4^{\text {th }}$ c. BC. $-\sigma^{\text {th }}$ c. AD). Turkestan: Akhmet Yassawi International Kazakh-Turkish University (in Russian).

8. Podushkin, A. N. 2019. In: Kazakhstan Archeology, 3 (5), 24-36 (in Russian).

9. Podushkin, N. P. 1974. In: Akishev, K. A. (ed.). V glub vekov (Into the depths of the centuries). Alma-Ata: "Nauka" Publ., 78-84 (in Russian).

10. Svod pamyatnikov istorii i kultury Kazahstana. Yuzhno-Kazahstanskaya oblast (The collection of monuments of history and culture of Kazakhstan. South Kazakhstan region). 1994. Almaty: "Kazakh enciklopediyasy" (in Russian).

11. Senigova, T. N. 1962. In: Trudy Instituta istorii, arheologii i etnografii Akademii nauk KazSSR (Proceedings of the Institute of History, Archeology and Ethnography of the Academy of Sciences of the Kazakh SSR), 14, 57-82 (in Russian).

12. Senigova, T. N., Mershchiev, M. S., Maksimova, A. G. 1962. In: Trudy Instituta istorii, arheologii i etnografii Akademii nauk KazSSR (Proceedings of the Institute of History, Archeology and Ethnography of the Academy of Sciences of the Kazakh SSR), 14, 57-116 (in Russian).

\footnotetext{
Мүдделер қақтығысы туралы ақпаратты ашу. Автор мүдделер қақтығысының жоқтығын мәлімдейді. / Раскрытие информации о конфликте интересов. Автор заявляет об отсутствии конфликта интересов. / Disclosure of conflict of interest information. The author claim no conflict of interest.
}

Мақала туралы ақпарат / Информация о статье / Information about the article.

Редакцияға түсті / Поступила в редакцию / Entered the editorial office: 11.05.2021.

Рецензенттер мақұлдаған / Одобрено рецензентами / Approved by reviewers: 05.06.2021.

Жариялауға қабылданды / Принята к публикации / Accepted for publication: 08.06.2021. 